\title{
Observations on oral betamethasone-17-valerate in the treatment of idiopathic steatorrhoea
}

\author{
A. T. OTAKI, J. R. DALY, AND A. MORTON-GILL \\ From the Gastroenterological Clinic, West London Hospital, and the Department of Chemical \\ Pathology, Charing Cross Hospital Medical School, London
}

EDITORIAL COMMENT Clinical remission in three patients with idiopathic steatorrhoea was achieved with Betnovate without getting corticosteroid side-effects or adrenocortical suppression.

The efficacy of corticosteroids in the treatment of idiopathic steatorrhoea has been repeatedly demonstrated (Adlersberg, Colcher, and Drachman, 1951; Adlersberg, 1955; Mackay and Volwiler, 1955; Moeschlin and Meyer, 1961 ; Frič, Bednār, Niederle, and Lepšik, 1963). The limiting factor in their use has been the threat of side-effects (Badenoch, 1960).

A number of adults with idiopathic steatorrhoea are not gluten-sensitive (French, Hawkins, and Smith, 1957), hence the choice of therapy in such patients is between severe dietary restriction and corticosteroid therapy.

McKenzie and Atkinson (1964) showed that topical betamethasone - 17 - valerate (Betnovate, Glaxo) is $\mathbf{4 0 0}$ times more active than betamethasone itself, judged by the production of skin vasoconstriction. Oral Betnovate appears less active than betamethasone as judged by its effect on the plasma cortisol level nevertheless it seems effective when administered in cases of ulcerative colitis and Crohn's disease (Gill, Otaki, Daly, and SpencerPeet, 1965).

This paper reports our initial observations on the effect of oral Betnovate in three cases of idiopathic steatorrhoea.

\section{METHODS}

The clinical condition and chemical status of three patients were assessed before and during treatment with Betnovate.

FAECAL Fat This, by the method of Van de Kamer, ten Bokkel Huinink, and Weyers (1949), was determined from two three-day collections. The normal is less than 6 g. daily.

VITAMIN A ABSORPTION This was studied by the method of Paterson and Wiggins (1954). Normal is a rise of more than 500 units $/ 100 \mathrm{ml}$.
URINE XYLOSE The results, determined by the method of Roe and Rice (1948), were expressed as the percentage of the oral dose excreted in the five hours following administration. Normal is more than $25 \%$.

PLASMA IRON The normal range for men is 80-175 $\mu \mathrm{g} . / 100 \mathrm{ml}$. and for women $60-160 \mu \mathrm{g} . / 100 \mathrm{ml}$., using Ramsay's (1958) method.

PLASMA VITAMIN B $_{12}$ The method was based on that of Spray (1955) and Matthews (1962) using Lactobacillus leishmanii. The normal range is $150-900 \mu \mu \mathrm{g} . / \mathrm{ml}$.

PLASMA FOLIC ACID Plasma folic acid activity was determined with Lactobacillus casei. Normal range is 5-25 $\mu \mathrm{mg} . / \mathrm{ml}$.

PLASMA CORTISOL Plasma cortisol was determined by the method of Spencer-Peet, Daly, and Smith (1965). Normal range is $5-26 \mu \mathrm{g} . / 100 \mathrm{ml}$.

ADRENOCORTICAL RESPONSIVENESS This was assessed by estimating the plasma cortisol level before and $30 \mathrm{~min}$. after intramuscular injection of synthetic $\beta^{1.24}$ corticotrophin (Synacthen) ${ }^{1}$. A normal response is a rise of between 7.5 and $27.5 \mu \mathrm{g} . / 100 \mathrm{ml}$. after 30 minutes (Wood, Frankland, James, and Landon, 1965).

\section{CASE HISTORIES}

CASE 1 In Mrs. H., aged 54, idiopathic steatorrhoea was diagnosed in 1946, and a gluten-free diet was started in 1956. Following a relapse in 1961 she was treated with prednisolone. In 1963 a jejunal biopsy showed subtotal villous atrophy (Fig. 1). In May 1965 she was admitted with megaloblastic anaemia. After treatment with haematinics the prednisolone was slowly reduced. The patient relapsed in October 1965. Steatorrhoea was severe with five or six stools daily. Betnovate $2 \mathrm{mg}$. daily was begun. In four days bowel actions had fallen to one daily and the stools appeared normal. She was able to take a normal diet without symptoms.

${ }^{1}$ Ciba Laboratories Ltd., Horsham, Sussex. 


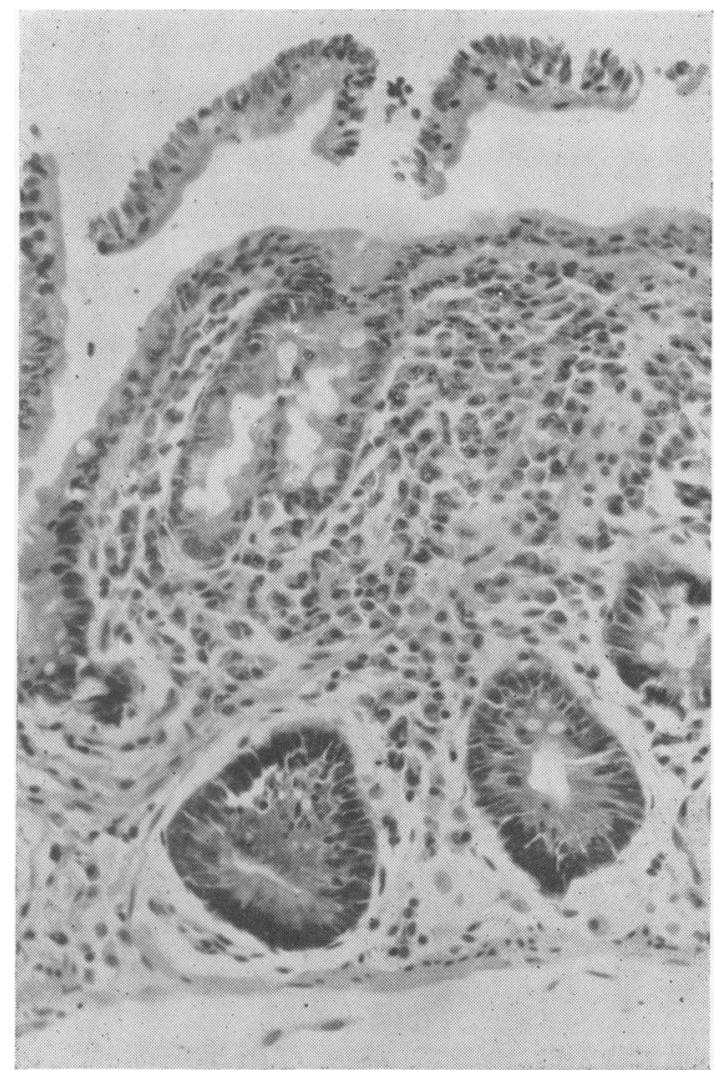

FIG. 1. Patient Mrs. H. Jejunal biopsy. Subtotal villous atrophy. Haematoxylin and eosin $\times 100$.

On reassessment after 31 days of Betnovate therapy the patient felt completely well and the daily bowel action appeared normal. However, there were still chemical abnormalities so the dose of Betnovate was increased to $3 \mathrm{mg}$. per day.

At a second reassessment after 95 days of treatment the improvement had been maintained. There was one bowel action daily and the stool appeared normal. Her diet was full and varied. The steatorrhoea was further reduced, but the plasma vitamin $\mathbf{B}_{12}$ level had fallen. There were no signs of hypercorticism and a Synacthen test showed that although the plasma cortisol level at 10 a.m. was subnormal there was a significant rise after 30 minutes.

Details of the main findings are shown in Table I.

CASE 2 Mrs. D., aged 60, had had episodes of diarrhoea and weight loss in childhood and early teens. In 1952, after a gynaecological operation, diarrhoea returned. Weight loss and severe diarrhoea led to her investigation at another hospital in 1963. Defective glucose, xylose, and fat absorption were present with villous atrophy of the jejunal mucoa, and idiopathic steatorrhoea was diagnosed. She was given a gluten-free diet which produced a notable improvement. However, a few months before being referred to us she resumed a normal diet. In June
TABLE I

INVESTIGATIONS ON MRS. H., AGED 54, BEFORE AND DURING BETNOVATE THERAPY

\begin{tabular}{|c|c|c|c|}
\hline \multirow[t]{3}{*}{ Test } & \multicolumn{3}{|l|}{ Date } \\
\hline & \multirow{2}{*}{$\begin{array}{l}19 \text { October } \\
1965 \\
\text { Before } \\
\text { Betnovate } \\
\text { Therapy }\end{array}$} & \multirow{2}{*}{$\begin{array}{l}24 \text { November } \\
1965 \\
\text { Betnovate } \\
\text { for } \\
31 \text { Days }\end{array}$} & \multirow{2}{*}{$\begin{array}{l}25 \text { January } \\
1966 \\
\text { Betnovate } \\
\text { for } \\
95 \text { Days }\end{array}$} \\
\hline & & & \\
\hline Stools per day & $5-6$ & 1 & 1 \\
\hline $\begin{array}{l}\text { Body weight (lb.) } \\
\text { Blood pressure }\end{array}$ & $133 \frac{1}{2}$ & 130 & $135 \frac{1}{2}$ \\
\hline $\begin{array}{l}(\mathrm{mm} . \mathrm{Hg}) \\
\text { Haemoglobin }\end{array}$ & $130 / 90$ & $125 / 80$ & $138 / 80$ \\
\hline & $12 \cdot 2(84 \%)$ & $13.0(89 \%)$ & $12 \cdot 1(83 \%)$ \\
\hline $\begin{array}{l}(\mathrm{mm} .) \\
\text { Faecal fat }\end{array}$ & 20 & 10 & 4 \\
\hline $\begin{array}{c}\text { (g. per day) } \\
\text { Xylose absorption }\end{array}$ & $27 \cdot 2$ & $10 \cdot 2$ & $7 \cdot 7$ \\
\hline & 9 & 10 & 30 \\
\hline absorption (i.u.) & 130 to 250 & 84 to 210 & 84 to 294 \\
\hline $\begin{array}{l}\text { Plasma proteins } \\
(\mathrm{g} . / 100 \mathrm{ml} .)\end{array}$ & $\begin{array}{l}\text { Total }=6.0 \\
\text { (albumin }=3.1)\end{array}$ & - & $\begin{array}{l}\text { Total }=6.7 \\
(\text { albumin }=3.7)\end{array}$ \\
\hline Plasma folic acid & $\begin{array}{l}\text { Folic acid i.m. } \\
15 \mathrm{mg} . / \text { week }\end{array}$ & $11 \cdot 5$ & 50 \\
\hline $\begin{array}{l}\text { Plasma vitamin } \\
\mathbf{B}_{12}(\mu \mu \mathrm{g} . / \mathrm{ml} .) \\
\text { Plasma iron }\end{array}$ & Vitamin $B_{12}$ i.m & $\begin{array}{l}190 \\
190\end{array}$ & $\begin{array}{l}90 \\
90\end{array}$ \\
\hline$(\mu \mathrm{g} . / 100 \mathrm{ml})$. & 74 & 100 & 62 \\
\hline $\begin{array}{l}\text { Plasma cortisol } \\
\text { before Synacthen } \\
(\mu \mathrm{g} / 100 \mathrm{ml})\end{array}$ & $23 \cdot 3$ & $17 \cdot 0$ & 2.8 \\
\hline $\begin{array}{l}\text { Plasma cortisol } 30 \\
\text { min. after Synac- } \\
\text { then }(\mu \mathrm{g} . / 100 \mathrm{ml})\end{array}$ & & & \\
\hline $\begin{array}{l}\text { then }(\mu \mathrm{g} . / 100 \mathrm{ml} .) \\
\text { Plasma cortisol } 60 \\
\text { min. after Synac- } \\
\text { then }(\mu \mathrm{g} . / 100 \mathrm{ml} .) \\
\text { Betnovate }(\mathrm{mg} . / \text { day })\end{array}$ & $20 \cdot 0$ & $\begin{array}{c}41 \cdot 3 \\
2\end{array}$ & $\begin{array}{c}19 \cdot 3 \\
3\end{array}$ \\
\hline
\end{tabular}

1965 when she first attended she had had several bouts of diarrhoea. She complained of fatigue, postprandial faintness, and morning urgency with five or six fluid offensive stools a day.

She was admitted in September 1965. A lactose tolerance test produced a rise of blood glucose in excess of $20 \mathrm{mg}$. $/ 100 \mathrm{ml}$. and did not cause diarrhoea. Synacthen stimulated normal adrenal activity. The patient was discharged to take $2 \mathrm{mg}$. of Betnovate daily. Three days later she was passing only two normal stools a day despite a normal diet.

In November after 53 days of treatment with $2 \mathrm{mg}$. of Betnovate she was admitted for reassessment. The improvement had been maintained, and the patient said she had not felt so well for a year and could now eat 'loads of bread'. There was still some chemical evidence of malabsorption, but faecal fat was only $5.7 \mathrm{~g}$. per day. A second reassessment took place after 120 days. The only abnormality detected was a low plasma folic acid level. Synacthen produced a normal adrenocortical response. There were no signs of hypercorticism. Treatment was continued with $2 \mathrm{mg}$. of Betnovate daily.

Details of the main clinical and laboratory findings are shown in Table II. 
TABLE II

INVESTIGATIONS ON MRS. D., AGED 53, BEFORE AND DURING BETNOVATE THERAPY

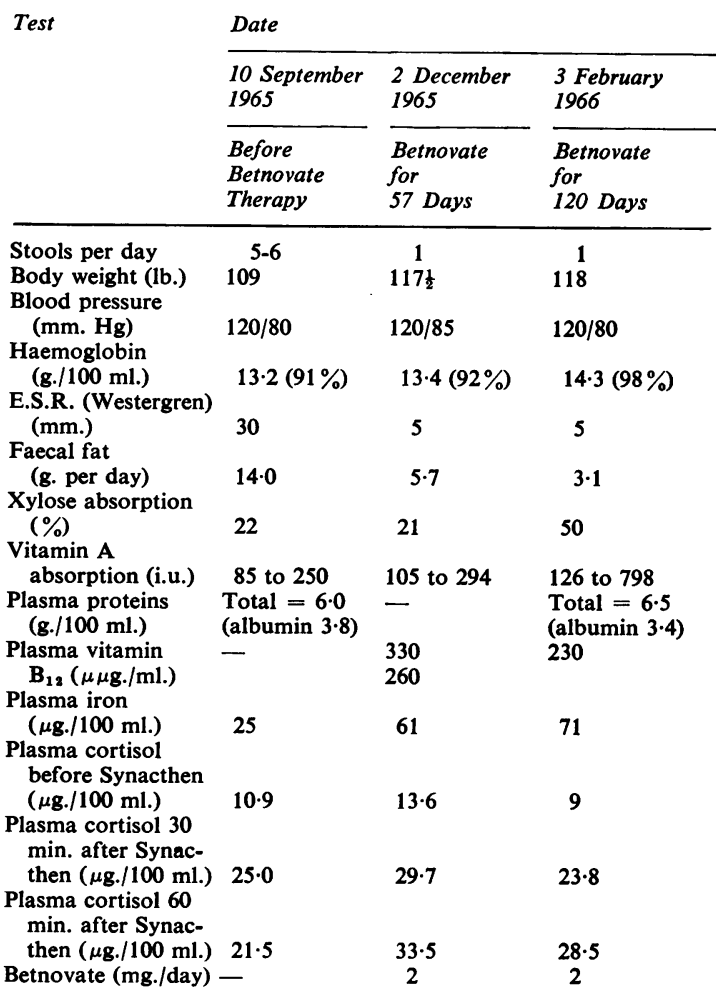

CASE 3 Mr. H., aged 53, began to have symptoms of idiopathic steatorrhoea in January 1962 and the diagnosis was confirmed by jejunal biopsy (Fig. 2). There was a satisfactory response to prednisolone but when the dose was reduced to $7.5 \mathrm{mg}$. the steatorrhoea relapsed. The patient was reassessed and the prednisolone reduced more slowly, but at $9 \mathrm{mg}$. daily a second relapse occurred.

He was readmitted in March 1965. There were two bulky, pale and urgent stools a day. The plasma cortisol level at $10 \mathrm{a} . \mathrm{m}$. was $1.5 \mu \mathrm{g} . / 100 \mathrm{ml}$., indicating pituitaryadrenal suppression. Prednisolone withdrawal was completed and the patient discharged on $2 \mathrm{mg}$. of Betnovate daily.

After 44 days of treatment he had gained weight, passed one formed stool each day, and was taking a normal diet.

After 98 days of treatment the remission continued. The plasma cortisol level at 10 a.m., and response to Synacthen were normal.

The patient was planning to return to Ireland and refused admission for reassessment. Believing himself to have returned to normal health he failed to keep an outpatient appointment in November to renew his supply of Betnovate. After omitting Betnovate for 19 days he was admitted at his own request in relapse. There was no evidence of adrenocortical failure. $\mathrm{He}$ was once more

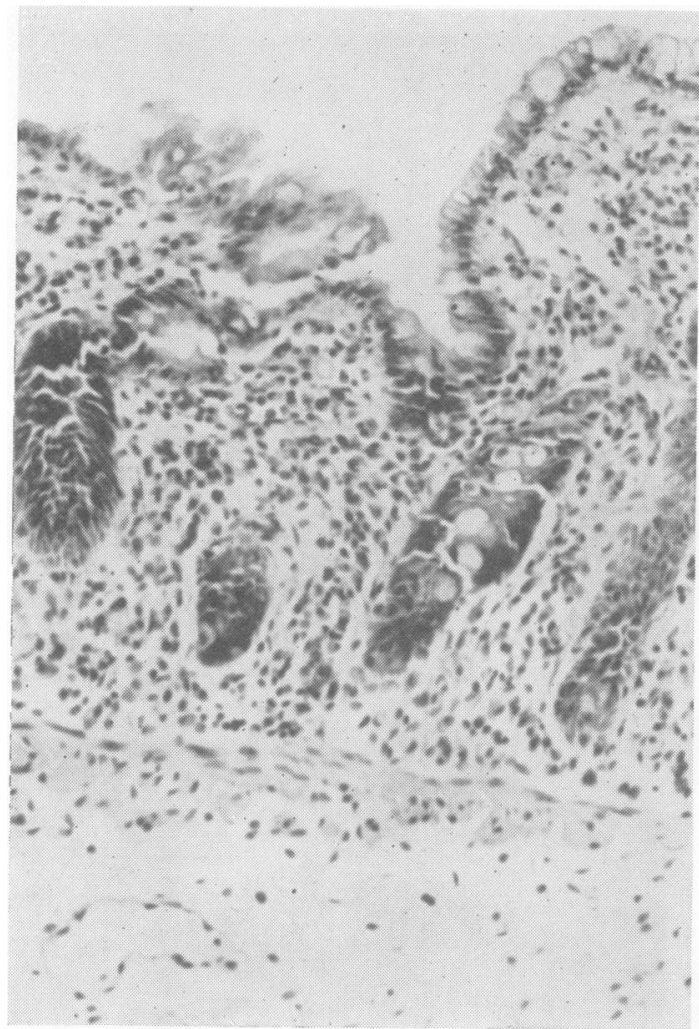

FIG. 2. Patient Mr. H. Jejunal biopsy. Subtotal villous atrophy. Haematoxylin and eosin $\times 100$.

passing two bulky pale stools daily and his body weight had fallen. Although he had received 204 days of Betnovate treatment before he stopped taking the tablets, his Synacthen response was normal.

Betnovate treatment was restarted and the patient left for Ireland. Details of the main findings are given in Table III.

\section{DISCUSSION}

Glyn and Fox (1961) showed betamethasone to be about seven times more potent than prednisolone. Topical Betnovate is very much more potent than topical betamethasone, but their relative systemic potencies, and hence the relative systemic potency of Betnovate and prednisolone, are not yet fully known.

The results presented here suggest that Betnovate has a good therapeutic effect in idiopathic steatorrhoea, with little tendency to produce side-effects on low, but efficacious doses. It may be that in order to correct the malabsorption completely a severe case may need more than $3 \mathrm{mg}$. a day with a correspondingly greater possibility of side-effects. If such cases are made symptom-free with small doses, and the mal- 
TABLE III

INVESTIGATIONS ON MR. H., AGED 53, BEFORE AND DURING RELAPSE AFTER BETNOVATE WITHDRAWAL

\begin{tabular}{|c|c|c|c|}
\hline \multirow[t]{3}{*}{ Test } & \multicolumn{3}{|l|}{ Date } \\
\hline & \multirow{2}{*}{$\begin{array}{l}8 \text { March } \\
1965 \\
\begin{array}{l}\text { Relapse during } \\
\text { Prednisolone } \\
\text { Reduction }\end{array}\end{array}$} & \multirow{2}{*}{$\begin{array}{l}29 \text { July } \\
1965 \\
\text { Betnovate } \\
\text { for } \\
98 \text { Days }\end{array}$} & \multirow{2}{*}{$\begin{array}{l}1 \text { December } \\
1965 \\
\text { No Betnovate } \\
\text { for } \\
19 \text { Days }\end{array}$} \\
\hline & & & \\
\hline Stools per day & 2 & 1 & 2 \\
\hline Body weight (lb.) & 115 & $129 \frac{1}{2}$ & - \\
\hline $\begin{array}{l}\text { Blood pressure } \\
(\mathrm{mm} . \mathrm{Hg})\end{array}$ & $100 / 65$ & $125 / 75$ & $120 / 70$ \\
\hline $\begin{array}{l}\text { Haemoglobin } \\
\quad(\text { g./ } 100 \mathrm{ml} \text {.) } \\
\text { E.S.R. (Westergren) }\end{array}$ & $12.4(85 \%)$ & $15 \cdot 1(104 \%)$ & $12 \cdot 4(85 \%)$ \\
\hline $\begin{array}{l}(\mathrm{mm} .) \\
\text { Faecal fat }\end{array}$ & 4 & 7 & 20 \\
\hline $\begin{array}{c}\text { (g. per day) } \\
\text { Xylose absorption }\end{array}$ & 6.7 & - & $25 \cdot 5$ \\
\hline $\begin{array}{l}(\%) \\
\text { Vitamin A }\end{array}$ & $11 \cdot 0$ & - & 9 \\
\hline absorption (i.u.) & 84 to 250 & - & 84 to 315 \\
\hline $\begin{array}{l}\text { Plasma vitamin } \\
\mathbf{B}_{12}(\mu \mu \mathrm{g} . / \mathrm{ml} .) \\
\text { Plasma iron }\end{array}$ & 180 & - & $\begin{array}{l}155 \\
120\end{array}$ \\
\hline $\begin{array}{l}(\mu \mathrm{g} . / 100 \mathrm{ml} .) \\
\text { Plasma cortisol }\end{array}$ & 108 & - & 69 \\
\hline & - & $11 \cdot 5$ & $10 \cdot 4$ \\
\hline $\begin{array}{l}\text { Plasma cortisol } 30 \\
\text { min. after Synac- } \\
\text { then }(\mu \mathrm{g} . / 100 \mathrm{ml} .)\end{array}$ & - & $20 \cdot 8$ & $28 \cdot 2$ \\
\hline $\begin{array}{l}\text { Plasma cortisol } 60 \\
\text { min. after Synac- } \\
\text { then }(\mu \mathrm{g} . / 100 \mathrm{ml} .) \\
\text { Betnovate }(\mathrm{mg} . / \mathrm{day})\end{array}$ & - & $\begin{array}{c}16 \cdot 9 \\
2\end{array}$ & $\underline{2}^{26 \cdot 7}$ \\
\hline
\end{tabular}

absorption of specific substances is corrected by supplementary treatment, the dose of Betnovate may be kept below that at which side-effects appear. More time is needed to assess fully the risk of side-effects with small oral doses of Betnovate, but on the doses used here none of the patients developed moon face or any other side-effect.

The Synacthen test provides a simple means of checking adrenal responsiveness during corticosteroid therapy. Patient 1 showed a normal response to Synacthen after 31 days of Betnovate in a dose of $2 \mathrm{mg}$. daily. After a further 63 days of $3 \mathrm{mg}$. daily the initial plasma cortisol level was subnormal but the response to Synacthen was in the normal range. Patient 2 showed a normal response after 120 days of treatment. Patient 3 had an impaired response before Betnovate was begun, but after 98 days of Betnovate therapy Synacthen responsiveness had returned to normal.

A study of the effect of Betnovate on the plasma cortisol level (Otaki and Daly, to be published) showed that it caused less depression than its parent compound betamethasone. The absence of sideeffects noted here with Betnovate, and its relatively slight depressing effect on adrenal responsiveness, may be due to its being comparatively poorly absorbed, or to its having a less marked systemic effect for metabolic reasons. This is at present under investigation.

If Betnovate is poorly absorbed, its beneficial effects in idiopathic steatorrhoea and in ulcerative colitis and Crohn's disease (Gill et al., 1965) are presumably due to a surface effect. This does not appear to be the only method by which steroids act on the gut because Almy (1951) obtained good results with A.C.T.H. and Moeschlin and Meyer (1961) with intravenous prednisolone.

These preliminary observations appear to indicate that Betnovate is a promising new addition to the therapy of steatorrhoea, for it shows a dissociation between its therapeutic action on the intestine and its suppressive effect on the pituitary adrenal axis.

\section{SUMMARY}

A satisfactory clinical remission was induced in three cases of idiopathic steatorrhoea using not more than $3 \mathrm{mg}$. daily of oral Betnovate (betamethasone-17valerate). Two patients were gluten-sensitive but all three patients were able to take a normal diet. Moderate chemical steatorrhoea persisted in one patient in whom vitamin $A$ absorption failed to improve. In two patients the plasma vitamin $\mathbf{B}_{12}$ level fell during treatment. There was no evidence of steroid side effects after treatment for 95 to 204 days. Betnovate did not lead to adrenocortical suppression as judged by the Synacthen stimulation test but the response was reduced in one patient. Betnovate appears to be suitable for the long-term treatment of idiopathic steatorrhoea but supplementary vitamin therapy may be necessary in some cases.

We thank Glaxo Laboratories Limited, Greenford, Middlesex, for generous supplies of Betnovate, and Mrs. L. Wallis for secretarial assistance. Ciba Laboratories Limited generously supplied Synacthen.

\section{REFERENCES}

Adlersberg, D. (1955). Problems of management of idiopathic sprue. N.Y. St. J. Med., 55, 3575-3582.

- Colcher, H., and Drachman, S. R. (1951). Studies on the effects of cortisone and pituitary adrenocorticotropic hormone (A.C.T.H.) in the sprue syndrome. Gastroenterology, 19, 674-697.

Almy, T. P. (1951). A refractory case of idiopathic steatorrhea (non-tropical sprue), with observations on the therapeutic effects of salt-poor human albumin and of the adrenocorticotropic hormone. Ann. intern. Med., 34, 1041-1048.

Badenoch, J. (1960). Steatorrhoea in the adult. Brit. med. J., 2 , 963-974.

French, J. M., Hawkins, C. F., and Smith, N. (1957). The effect of a wheat-gluten-free diet in adult idiopathic steatorrhoea. Quart. J. Med., 26, 481-499.

Frič, P., Bednáŕ, B., Niederle, B., and Lepšík, J. (1963). Jejunal adenocarcinoma in a woman with non-tropical sprue. Gastroenterology, 44, 330-334. 
Gill, A. M., Otaki, A. T., Daly, J. R., and Spencer-Peet, J. (1965). Oral betamethasone-17-valerate in chronic ulcerative colitis and Crohn's disease. Brit. med. J., 2, 29-31.

Glyn, J. H., and Fox, D. B. (1961). Preliminary clinical assessment of betamethasone. Ibid., 1, 876-877.

Mackay, I. R., and Volwiler, W. (1955). The effect of cortisone upon absorption of protein, fat, and calcium in idiopathic steatorrhea. Gastroenterology, 28, 972-980.

McKenzie, A. W., and Atkinson, R. M. (1964). Topical activities of betamethasone esters in man. Arch. Derm. (Chic.), 89, 741-746.

Matthews, D. M. (1962). Observations on the estimation of serum vitamin $\mathbf{B}_{12}$ using Lactobacillus leichmannii. Clin. Sci., 22, 101-111.

Moeschlin, S., and Meyer, P. G. (1961). Behandlung der idiopathischen Sprue (4 Fälle) durch parenterale Corticosteroidtherapie (Prednisolon, Dexamethason). Schweiz. med. Wschr., 91, 320-326.

Paterson, J. C. S., and Wiggins, H. S. (1954). An estimation of plasma vitamin A and the vitamin A absorption test. J. clin. Path.; 7, 56-60.

Ramsay, W. N. M. (1958). Plasma iron. In Advances in Clinical Chemistry, 1, 1-39, edited by H. Sobotka, and C. P. Stewart, Academic Press, New York.

Roe, J. H., and Rice, E. W. (1948). A photometric method for the determination of free pentoses in animal tissues. J. biol. Chem., 173, 507-512.

Spencer-Peet, J., Daly, J. R., and Smith, V. (1965). A simple method for improving the specificity of the fluorimetric determination of adrenal corticosteroids in human plasma. J. Endocr., 31, 235-244.

Spray, G. H. (1955). An improved method for the rapid estimation of vitamin $B_{18}$ in serum. Clin. Sci., 14, 661-667.

Van de Kamer, J. H., ten Bokkel Huinink, H., and Weyers, H. A. (1949). Rapid method for the determination of fat in feces. J. biol. Chem., 177, 347-355.

Wood, J. B., Frankland, A. W., James, V. H. T., and Landon, J. (1965). A rapid test of adrenocortical function. Lancet, 1, 243-245. 